\title{
REFORMING PROCUREMENT LAW IN SOUTH AFRICA
}

\author{
Geo Quinot
}

\section{(2020) 7 APPLJ 1}

\begin{abstract}
The reform of South African public procurement law has been on the cards for many years. Following years of promises from government leaders and officials about a new procurement law, a draft Public Procurement Bill for South Africa was eventually published for public comment in February 2020. The draft Bill proposes a complete overhaul of South African procurement law by consolidating existing procurement rules into a single statutory regime. It creates new institutional structures and a new dispute resolution process. There are, however, a number of problems with the draft Bill that should be addressed before the draft can proceed on its path to becoming a new overarching procurement statute in South Africa.
\end{abstract}

This contribution introduces a special edition of the African Public Procurement Law Journal focusing on the draft Bill. In subsequent contributions, specific aspects of the draft Bill will be considered in more detail. 


\section{REFORMING PROCUREMENT LAW IN SOUTH AFRICA}

Geo Quinot

BA(Law) LLB LLM MA MPA LLD

Professor, Department of Public Law, Stellenbosch University \& Director, African

Procurement Law Unit

\section{Introduction}

A new public procurement statute for South Africa has been on the cards for a number of years now. At least since 2013 the Minister of Finance has mooted major regulatory reform in public procurement. In its 2015 Public Sector Supply Chain Management Review, National Treasury stated that the Office of the Chief Procurement Officer (OCPO) was in the process of preparing a draft "Supply Chain Management Bill" and in his 2017 Budget Speech, the Minister of Finance stated that a

"draft Public Procurement Bill will be published shortly. It will establish a single procurement authority and will consolidate the currently fragmented regulatory environment, in keeping with section 217 of the Constitution."1

This statement was repeated in the 2018 Budget Speech, with the Minister also indicating a timeframe for this development, when he stated:

"The Public Procurement Bill will be submitted to Cabinet in March 2018 for gazetting for public comments."2

It was only two years later, in February 2020, that a draft Public Procurement Bill ${ }^{3}$ was published for public comment.

The development of a new statutory instrument to govern public procurement in South Africa has thus been long in the making and is eagerly anticipated by the public procurement market and everyone involved in it.

\footnotetext{
${ }^{1}$ Gordhan 2017.

${ }^{2}$ Gigaba 2018.

${ }^{3}$ Hereafter referred to as "the Bill".
} 
In this brief contribution, which introduces this special edition focusing on the Bill, I will outline the drivers behind the procurement-law reform process in South Africa. In my view, these should serve as the main measures to judge the success of the Bill. I will subsequently raise a number of red flags in respect of the Bill. This will not be an exhaustive list of potential problems, nor will it provide any in-depth analyses of these issues or how to resolve them. Most of these issues will be addressed in more detail in the other contributions to this special edition.

\section{The drivers of procurement-law reform in South Africa}

There are numerous drivers of the reform of public procurement law in South Africa. One of the most important is the current state of South African procurement law. Despite a provision in the Constitution ${ }^{4}$ capturing in concise terms the five main principles animating procurement law, namely fairness, equity, transparency, competition and cost-effectiveness, there is very little coherence below the Constitution in how procurement law is constituted. There are many different statutes that contain some rules on procurement. These include at least the following:

1. Preferential Procurement Policy Framework Act 5 of 2000 ("PPPFA")

2. Public Finance Management Act 1 of 1999 ("PFMA")

3. Local Government: Municipal Finance Management Act 56 of 2003 ("MFMA")

4. Local Government: Municipal Systems Act 32 of 2000

5. Broad-based Black Economic Empowerment Act 53 of 2003

6. State Tender Board Act 86 of 1968

7. Prevention and Combating of Corrupt Activities Act 12 of 2004 ("Corruption Act")

8. Construction Industry Development Board Act 38 of 2000 ("CIDB Act")

9. National Land Transport Act 5 of 2009

10. State Information Technology Agency Act 88 of 1998

11. Armaments Corporation of South Africa, Limited Act 51 of 2003

12. Public Service Act 1994

13. Public Administration Management Act 11 of 2014

14. Correctional Services Act 111 of 1998

15. National Supplies Procurement Act 89 of 1970

\footnotetext{
${ }^{4}$ Constitution of the Republic of South Africa, 1996 s 217.
} 
16. Financial Management of Parliament Act 10 of 2009

17. Road Traffic Management Corporation Act 20 of 1999

18. Administrative Adjudication of Road Traffic Offences Act 46 of 1998

19. Nursing Act 33 of 2005

20. Public Audit Act 25 of 2004

21. Health Professions Act 56 of 1974

22. Housing Act 107 of 1997

23. Disaster Management Act 57 of 2002

The scope of procurement rules contained in these distinct pieces of primary legislation differs significantly. It ranges from the entire PPPFA focusing exclusively on procurement to statutes that only contain a single section or two on procurement.

Under these pieces of legislation there are dozens of pieces of subordinate legislation dealing with aspects of procurement in all shapes and sizes, ranging from traditional regulations to instruction notes to codes and standards - all with varying levels of statutory authority.

There is significant overlap, duplication and even tension between all these various instruments. For example, currently there is serious regulatory tension in the context of infrastructure procurement between the Framework for Infrastructure Delivery and Procurement Management and its predecessor, the Standard for Infrastructure Procurement and Delivery Management, issued under the PFMA on the one hand and the construction procurement rules issued by the Construction Industry Development Board under the CIDB Act on the other hand. Another example of regulatory overlap is debarment in South African procurement law. There are two distinct debarment registers premised on completely separate regulatory bases. The Register for Tender Defaulters caters for debarment in terms of the Corruption Act. The Database for Restricted Suppliers caters for debarment under the PFMA/PPPFA. These two registers may, however, cover the exact same abuse of procurement processes. ${ }^{5}$ While the Database for Restricted Suppliers captures debarment under both the PFMA and PPPFA, the procedures and exact reasons for restricting a supplier by means of

\footnotetext{
${ }^{5}$ See Williams \& Quinot: 2007; Williams \& Quinot: 2008.
} 
listing on this database are not aligned under the two statutes, leading to significant uncertainty about the lawfulness of debarment decisions.

In addition to the mass of overlapping statutory rules governing procurement, as the Constitutional Court stated in Allpay Consolidated Investment Holdings (Pty) Ltd v Chief Executive Officer of the South African Social Security Agency, ${ }^{6}$ procurement law in South Africa is not statutorily consolidated or codified so that general administrative law, including the Promotion of Administrative Justice Act 3 of 2000 ("PAJA"), and general contract law, including common law, as well as increasingly general constitutional law, especially after the Constitutional Court judgment in State Information Technology Agency SOC Limited v Gijima Holdings (Pty) Limited, ${ }^{7}$ apply to procurement disputes.

There is thus a lot of law spread out over a large field that apply to public procurement in South Africa. In the face of this extreme level of fragmentation in the regulatory regime, one of the most important objectives of the procurement-law reform must thus be consolidation.

The Bill explicitly acknowledges the aim of consolidation of the fragmented regulatory regime as one of the key drivers of this reform. Already in the Preamble, it states one of the objectives of the Bill as to "create single regulatory framework for public procurement to eliminate fragmented procurement prescripts". This is repeated in the objects provision in section 2(e). The memorandum on objects of the Bill, published with the Bill, again echoes the aim of consolidation.

There are also more substantive arguments driving the procurement law reform process. One of the main issues in this respect is the perception that the current approach to procurement as a tool for transformation is not delivering adequate results. There has been growing criticism of what is generally known as preferential procurement, referring to the use of public procurement to address the inequalities of the South African economy. The blame for a perceived lack of progress in transforming the economy has partially been placed on the PPPFA and its perceived rigidity in what

\footnotetext{
${ }^{6} 2014$ (1) SA 604 (CC).

${ }^{7} 2018$ (2) SA 23 (CC).
} 
measures it allows. ${ }^{8}$ There is accordingly a need to revisit the preferential procurement regime.

There has also been growing concern about the remedies regime in South African procurement law. Procurement has become a major area of litigation for the public administration, ${ }^{9}$ resulting in significant delays in delivering projects and fulfilling public functions. The remedies granted in some of these cases have had a further adverse impact on the functioning of the procurement system. A prime example is that of holding individual procurement officials liable in their private capacities for losses flowing from botched procurement processes. ${ }^{10}$ There can be little doubt that this remedy will have a chilling effect on procurement processes in that public officials will shy away from serving on tender committees and where they do from taking decisions or encourage overly cautious approaches. The existing procurement remedies regime is arguably unable to deliver effective relief in procurement disputes in a manner that can balance the need for integrity in the process with efficient acquisition.

When evaluating the Bill, these are some of the main objectives against which the detailed provisions must be tested to determine whether the Bill proposes an improved procurement law regime in South Africa.

\section{A (non-exhaustive) list of red flags}

A number of concerns stand out for me in the Bill. This is not meant to be an exhaustive list of issues, nor do I intend to provide detailed analyses of any of these issues. They are, however, matters that deserve further deliberation in my view before this Bill can become the new South African procurement law.

\footnotetext{
${ }^{8}$ See Quinot 2019.

${ }^{9}$ Moseme Road Construction CC v King Civil Engineering Contractors (Pty) Ltd 2010 (4) SA 359 (SCA) para 1.

${ }^{10}$ Westwood Insurance Brokers (Pty) Ltd v Ethekwini Municipality and Others [2017] ZAKZDHC 15 (5 April 2017).
} 


\section{Institutional arrangements}

One of the main changes that the Bill introduces into the South African public procurement system is the creation of the Public Procurement Regulator. This entity is granted overall regulatory powers in relation to public procurement across all levels of government. It is not a centralised procuring entity, that is, it is not a return to the erstwhile State Tender Board. The Regulator's role under the Bill is largely to implement the Bill, ensure that the procurement system functions properly within the regulatory prescripts and act as a dispute resolution mechanism. It is granted extensive powers to create additional rules or prescripts under the Bill (I shall return to this issue below).

The conceptualisation of the Regulator and its powers under the Bill deserve a full contribution on its own. In this brief introduction, I will only flag one aspects of the Regulator that I perceive to be problematic. That is the independence of the Regulator.

The Regulator is created within National Treasury (section 4). In this sense the Regulator will largely replace the current Office of the Chief Procurement Officer. Section 4(2) obliges the Head of the Regulator to ensure that the Regulator exercises its mandate "impartially" and "without fear, favour or prejudice". There are, however, no further mechanisms in the Bill that would effectively enable the Regulator to act in this independent manner. In fact, the Bill provides virtually no further guidance on the institutional functioning of the Regulator. For example, the Bill says nothing about the appointment or dismissal of the Head of Regulator or to whom this person is accountable. In the absence of any such provisions, one must assume that the Regulator will function as a unit of National Treasury alongside all other divisions and will thus be subject to the same oversight and control mechanisms within the Department.

This institutional arrangement will hardly result in any form of independence for the Regulator. Simply put, the Regulator will not be independent from national government. In my view, this lack of independence will greatly undermine the potential effectiveness of the Regulator in fulfilling its oversight function. It will exist within the same departmental relationships as all other divisions of National Treasury, which means that it will not enjoy any particular enhanced standing to ensure that 
procurement across all organs of state is aligned to a single regulatory vision. The cross-cutting role of procurement across different departmental mandates will be lost within this institutional arrangement. That is, the role that procurement plays in delivering on policy mandates across all government departments, either directly as in the industrial development or wealth redistribution roles of procurement in South Africa or indirectly, in facilitating public programmes such as infrastructure development or a national health insurance scheme, will not be optimally served by this institutional arrangement. With this arrangement, procurement remains wholly conceptualised as exclusively within the public finance domain to the detriment of these other important conceptualisations.

The lack of effective independence will also put the dispute resolution function of the Regulator at risk. Without proper independence, it is questionable whether aggrieved suppliers will be satisfied with the orders issued by the Regulator when a matter is appealed to it. If suppliers regard the Regulator as too close to government, in effect as part of government, it is to be expected that they will still proceed to courts to resolve procurement disputes, which would undermine the purpose of the new dispute resolution mechanisms created in the Bill.

\section{Preferential procurement}

The complete repeal of the PPPFA comes as no surprise. As noted above, the reform of the preferential procurement regime is one of the main drivers of procurement law reform and it was thus always expected that a new law will involve significant changes to the existing PPPFA regime. Of particular concern, however, is what the PPPFA is replaced with. Even though it is called a chapter in the Bill (chapter 4), the Bill in fact contains only a single provision on preferential procurement (section 26). Moreover, this section does not really tell us much. As is the case with many aspects of the Bill, section 26 simply leaves it to the Minister to create a preferential procurement regime. In terms, section 26(1) states that

"The Minister must prescribe a framework for preferential treatment for categories of preferences, and the protection or advancement of persons, or categories of persons, previously disadvantaged by unfair discrimination, in procurement." 
In my view, this is problematic in light of section 217 of the Constitution. Section 217(2) explicitly allows for "categories of preference in the allocation of contracts" and "the protection or advancement" of persons previously discriminated against in the public procurement system. However, section 217(3) places a very important restriction on these measures by providing that "[n]ational legislation must prescribe a framework within which the policy referred to in subsection (2) must be implemented." The Constitution is thus explicit that the framework for preferential procurement must by prescribed in national legislation. I have serious reservations about the constitutionality of simply delegating this power to create the framework to the Minister. In my view, the framework should be created in the legislation itself, as is currently the case under the PPPFA.

\section{E-Procurement}

The Bill explicitly states that it aims to "provide for procurement that uses technology to simplify procurement processes and better leverage economies of scale" (section 2(b)(v)). In support of this aim it empowers the newly created Procurement Regulator to "promote the use of technology in procurement" (section 5(1)(k)) and the Minister to issue regulations regarding "the use of information and communications technology in procurement" (section 121(1)(g)). The Bill furthermore contains an explicit provision (section 15) stating that "Institutions must, to the extent possible, use information and communication technology to implement any of the procurement methods in this Act."

All of this suggests that the Bill is, at long last, forcing the South African public procurement system to embrace e-procurement at an increased pace than has hitherto been the case. ${ }^{11}$ However, I am not convinced that these nods in the direction of e-procurement are genuinely embedded within the Bill's paradigm of procurement. There are many examples in the Bill where an outdated, manual and paper-based paradigm of procurement seeps through. For example, the Bill explicitly provides for the opening of bids in section 36. While the rules governing such opening may be read to include e-procurement, the formulation of the section clearly reflects a manual paradigm of procurement where bids "must be opened at the time and place indicated" (section 36(1)), "a bidder or his or her representative is authorised to attend the

\footnotetext{
${ }^{11}$ See Kramer 2016.
} 
opening of bid session" (section 36(3)), the "name of the bidder, the total amount of each bid ... must be read out" (section 36(4). Another, more puzzling example, is found in section 41. This section obliges an institution to "forward a written request to the Regulator to verify if a preferred bidder, or any of that bidder's directors, members, trustees or partners, is listed on the register for bidders and suppliers debarred". This manual approach is puzzling given that this exact same function is currently done by way of technological solutions in the form of the different lists of debarred suppliers that are published on the internet on National Treasury's website and the central supplier database where this information is captured against the registration of all suppliers.

In my view, the Bill is not doing enough to push the South African public procurement system into the $21^{\text {st }}$ century by adopting a stronger e-procurement paradigm.

\section{Continued proliferation of laws}

As noted above, one of the key drivers of the current procurement law reform is the fragmentation of procurement law in South Africa. A major contributing factor to this fragmentation has been the issuing of dozens of subordinate pieces of legislation by especially National Treasury under the PFMA and PPPFA.

I am concerned that the powers granted to the newly created Procurement Regulator to issue all kinds of binding instruments will simply continue this trend. The Regulator is given the power to "determine a model procurement policy" (section 5(2)(d)), to "issue a directive to declare certain procurement practices as undesirable" (section $5(2)(f))$ and to "issue binding instructions in accordance with this Act" (section 5(2)(g)). In addition, provincial treasuries are empowered to "issue provincial instructions on procurement" (section 9(2)(a)).

On top of all these binding instruments that may be issued by the Regulator and provincial treasuries, the Minister is also granted extensive powers to create regulations (section 121). The Minister's power to create regulations is highly circumscribed in terms of both the substantive issues to be covered and especially the procedures to be followed. In form, the regulation-making powers under the Bill are significantly more controlled than equivalent powers in other statutes. It is curious, however, that the powers of the Regulator and provincial treasuries to issue (also 
binding) instruments under the Bill are not controlled in form at all. That is, there is no prescribed procedures to be followed when either of these entities issue further rules under the Bill. It is curious that the Minister would be subjected to extensive procedural control, but entities lower in the executive hierarchy would be left largely unchecked in terms of procedure.

\section{Silence on local government}

The Bill proposes to revoke the entire chapter 11 of the MFMA (section 123 read with the schedule). This means that the current provisions dealing with procurement at local government level will be wholly subsumed under the Bill. This is a very significant change since local government procurement has been governed completely separately from other levels of government to date.

If one reads the Bill from a local government perspective, a number of red flags arise. In fact, it is not clear that local government was given much thought in many of the provisions in the Bill.

The prime example is the dispute resolution mechanisms created in chapter 9. While detailed provision is made for provincial and national reconsideration of procurement decisions, the chapter is near silent on how disputes at local government level will be dealt with. It seems that municipalities will be obliged to reconsider their own procurement decisions upon application as is the case for all procuring entities at all levels of government (section 96). However, it is far from clear what should happen after that. Following reconsideration by the entity under section 96 , section 97 provides for reconsideration by a provincial treasury of "a decision made by an institution in the provincial sphere of government" and section 98 provides for reconsideration by the Regulator of "a decision made by an institution in the national sphere of government". There is no equivalent provision explicitly dealing with decisions made by an institution at the local sphere of government. Furthermore, access to the newly created Public Procurement Tribunal is only via decisions by provincial treasuries and the Regulator. In other words, one will only be able to take a decision on review to the Tribunal after you have approached a provincial treasury or the Regulator for reconsideration. The question emerges of where this leaves local government. Does this imply that the Tribunal will have no jurisdiction over local government procurement? 
The Bill is in my view currently not adequately focused on local government procurement and requires careful reconsideration in this light.

\section{Conclusion}

The publication of the draft Public Procurement Bill, 2020, is definitely a welcome development in the reform of South African public procurement law. Such reform is long overdue and is urgent in light of the mountain of challenges facing public procurement in South Africa. If one bears in mind the massive role that public procurement plays in all aspects of public administration, this need for reform becomes even more urgent given the knock-on effect of poor procurement on government generally. This has been vividly brought home during the COVID-19 pandemic, when so many problems in dealing with the pandemic had something to do with procurement, like the struggle to reopen public schools because of failures in the procurement process of essential health and safety equipment necessary to ensure safety of learners and teachers. If one furthermore bears the massive scale of public procurement in mind, in South Africa government currently spends about a trillion rand on public procurement, which is 1.3 times what it spends on wages, ${ }^{12}$ the urgency is again increased. Even before the COVID-19 pandemic, the South African economy faced major challenges and government spending was under severe pressure. With the pandemic, this pressure has exponentially increased. It is thus also from a public finance and economic perspective imperative that the system be reformed to increase efficiencies and value for money in public spending.

I hope that the publication of the Bill and the public engagement process following that publication will accelerate and deepen public debate around the South African public procurement system. In its current form, I do not think that the Bill presents us with the tool we need to meaningfully reform our procurement system, but I do think that it provides us with a good basis to start a robust conversation around what that ideal tool should eventually look like. This special edition of the African Public Procurement Law Journal is aimed at contributing to that debate.

\footnotetext{
12 Brunette \& Klaaren 2020.
} 


\section{Bibliography}

\section{Literature}

Brunette, R. \& Klaaren, J. 2020. Reforming the Public Procurement System in South Africa. Position Papers on State Reform. Public Affairs Research Institute. (online) Available at https://pari.org.za/position-papers-public-procurement/ (Accessed 21-052020).

Gigaba, M. 2018. Budget Speech. (online) Available at: http://www.treasury.gov.za/documents/national\%20budget/2018/speech/speech.pdf (Accessed 29-04-2020).

Gordhan, P. 2017. Budget Speech. (online) Available at: http://www.treasury.gov.za/documents/national\%20budget/2017/speech/speech.pdf (Accessed 29-04-2020).

Kramer, G. 2016. Electronic Public Procurement as a Tool of Reform in South African Public Procurement. African Public Procurement Law Journal 3: 1-41.

Quinot, G. 2019. Constitutionalising Public Procurement through Human Rights: Lessons from South Africa. In Martin-Ortega, O. \& Methven O'Brien, C. (Eds.). Public Procurement and Human Rights. Cheltenham: Edward Elgar Publishing.

Williams, S. \& Quinot, G. 2007. Public Procurement and Corruption: The South African Response. South African Law Journal 124: 339-363.

Williams, S. \& Quinot, G. 2008. To Debar or not to Debar: When to Endorse a Contractor on the Register for Tender Defaulters. South African Law Journal 125: 248258.

\section{Case law}

Allpay Consolidated Investment Holdings (Pty) Ltd $v$ Chief Executive Officer of the South African Social Security Agency 2014 (1) SA 604 (CC)

Moseme Road Construction CC v King Civil Engineering Contractors (Pty) Ltd 2010 (4) SA 359 (SCA) 
State Information Technology Agency SOC Limited v Gijima Holdings (Pty) Limited 2018 (2) SA 23 (CC)

Westwood Insurance Brokers (Pty) Ltd v Ethekwini Municipality and Others [2017] ZAKZDHC 15 (5 April 2017).

\section{Legislation}

Administrative Adjudication of Road Traffic Offences Act 46 of 1998

Armaments Corporation of South Africa, Limited Act 51 of 2003

Broad-based Black Economic Empowerment Act 53 of 2003

Constitution of the Republic of South Africa, 1996

Construction Industry Development Board Act 38 of 2000

Correctional Services Act 111 of 1998

Disaster Management Act 57 of 2002

Financial Management of Parliament Act 10 of 2009

Health Professions Act 56 of 1974

Housing Act 107 of 1997

Local Government: Municipal Finance Management Act 56 of 2003

Local Government: Municipal Systems Act 32 of 2000

National Land Transport Act 5 of 2009

National Supplies Procurement Act 89 of 1970

Nursing Act 33 of 2005

Preferential Procurement Policy Framework Act 5 of 2000

Prevention and Combating of Corrupt Activities Act 12 of 2004 
Promotion of Administrative Justice Act 3 of 2000

Public Administration Management Act 11 of 2014

Public Audit Act 25 of 2004

Public Finance Management Act 1 of 1999

Public Service Act 1994

Road Traffic Management Corporation Act 20 of 1999

State Information Technology Agency Act 88 of 1998

State Tender Board Act 86 of 1968 